\title{
Migration of an annual myrmecochore: a four year experiment with Melampyrum pratense $\mathrm{L}$.
}

\author{
Thilo Heinken \\ Institut für Biologie, Systematische Botanik und Pflanzengeographie, Freie Universität Berlin, \\ Altensteinstr. 6, D-14195 Berlin, Germany \\ Present address: Institut für Biochemie und Biologie, Biozönoseforschung/Spezielle Botanik, Univer- \\ sität Potsdam, Maulbeerallee 2a, D-14469 Potsdam, Germany (E-mail: heinken@rz.uni-potsdam.de)
}

Key words: artificial introduction, colonization, dispersal, myrmecochory, NE Germany, woodland herb

\begin{abstract}
A seed sowing experiment was conducted in a mixed secondary woodland on acidic soils in NE Germany with Melampyrum pratense, an annual ant-dispersed forest herb which lacks a natural population in the study area, but is abundant in similar habitats. Each set of 300 seeds was sown within one square metre at three sites in 1997, and the development of the populations was recorded from 1998 onward. Additionally, seed fall patterns were studied in a natural population by means of adhesive cardboard.

All trials resulted in the recruitment of populations, which survived and increased in both individual number and area, up to the year 2001. Thus, local distribution of Melampyrum pratense is dispersallimited. Total individual number increased from 105 to 3,390, and total population area from 2.07 to $109.04 \mathrm{~m}^{2}$. Migration occurred in all directions. Mean migration rate was $0.91 \mathrm{~m}$ per year, and the highest migration rate was $6.48 \mathrm{~m}$. No individual was recorded beyond $7.63 \mathrm{~m}$ from the centres of the sawn squares after three years, suggesting exclusive short-distance dispersal. As primary dispersal enables only distances of up to $0.25 \mathrm{~m}$, ants are presumed to be the main dispersal vectors. Despite differences in individual number and colonization patterns, migration rates did not differ significantly between the populations, but were significantly higher in 2001 due to an increased population size. Colonization patterns were characterized by a rapid, negative exponential decrease of population density with increasing distance from the sown plot, suggesting a colonization by establishment of more or less isolated outposts of individuals and a subsequent gradual infill of the gaps between.

My results resemble myrmecochorous dispersal distances in temperate woodlands, and migration rates and patterns across ecotones from ancient to recent deciduous forests. They may function as a colonization model of Melampyrum pratense after accidental long-distance dispersal.
\end{abstract}

\section{Introduction}

In recent years it has been widely recognized that the plant species composition and thus the phytodiversity of ecosystems is not only dependent on habitat conditions such as climate, edaphic factors and land use, but also on the accessibility of the habitats for plants (e.g. Poschlod et al.1996; Ehrlen und Eriksson 2000). As site conditions are rapidly altered by changing land use, pollution by nutrients, and perhaps global warming and changing rainfall patterns, species will go extinct locally unless they are able to migrate to new, suitable habitats (e.g. Primack \& Miao 1992; Higgins \& Richardson 1999).

Increasing interest has occurred in dispersal and establishment of temperate woodland plants. This interest is particularly due to the recognition of differences in the forest floor flora and vegetation between ancient and recent woodland on former arable land or grassland (e.g. Wulf 1997; Hermy et al. 1999). In NE Germany, as well as in several regions of Central Europe, isolated patches of forest are embedded in a generally inhospitable landscape of intensively managed farmland, roads and settlements. Afforestations nowadays are often created on former arable land, forest succession occurs on fallow land, and existing forest patches are strongly effected by changing management regimes and pollution. In contrast to most tree and shrub species, the majority of woodland herbs have a low ability to colonize newly created, or recolonize disturbed, habitats (e.g. Wulf 1997; Brunet \& Oheimb 1998; Bossuyt et al. 1999; Dzwonko 2001). This may be attributed to a complex of interacting variables, namely limited dispersal abilities (short-distance dispersal strategy), low diaspore production and recruitment problems (e.g. Hermy et al. 1999; Ehrlén \& Eriksson 2000; Verheyen \& Hermy 2001a).

While the majority of woodland herbs in northern temperate forests do not have morphological adaptations for dispersal by wind, adhesion, or ingestion (Bierzychudek 1982), ant-plant mutualisms represent one of the most common modes of seed dispersal (e.g. Handel et al. 1981). Since the studies of 
Sernander (1906) and the subsequent work of other botanists on the dispersal of seeds and fruits by ants, interest in myrmecochory has been greatly revived and broadened in the last decades (e.g. Culver \& Beattie 1978; Kjellsson 1985; Ohkawara \& Higashi 1994; Gorb \& Gorb 1995, 1999a). Ants move seeds on a strictly local scale, and dispersal distances as well as dispersal patterns of several myrmecochorous seed species - including Melampyrum spp. - are well documented (e.g. Higashi et al. 1989; Gibson 1993; Ohkawara et al. 1996; Cain et al. 1998; Kalisz et al. 1999).

However, we lack data on the spread of ant-dispersed woodland herbs, which are needed for predicting how species will distribute themselves in response to habitat loss and creation, and climate change (cf. Cain et al. 1998; Higgins \& Richardson 1999). To date, few studies have quantified the migration rates and patterns of forest plants, and these are investigations done once in second-growth stands of known age adjacent to ancient forests (Matlack 1994; Brunet \& Oheimb 1998; Bossuyt et al. 1999; Honnay et al. 1999; Dzwonko 2001). However, colonization patterns cannot solely be attributed to dispersal processes, as the recruitment of species in the recent forest stands is often limited by differing soil properties and canopy cover (e.g. Brunet et al. 2000; Verheyen \& Hermy 2001b). Thus, such studies should be supplemented with direct observations of migration of herbaceous forest plants from known release points in woodlands.

Petersen \& Philipp (2001) implanted 37 woodland herbs including several myrmecochores in a wood on former arable land and recorded survival and migration for ten years. However, most disappeared or did not increase in number or area. Only Ehrlén \& Eriksson (2000) conducted seed sowing experiments of forest herbs at unoccupied sites to assess factors that limit regional distributions, but spatial spread was not investigated. In order to study colonization, Primack \& Miao (1992) conducted such experiments only with four annual non-wood and non-myrmecochorous species.

In this study, I used the seed-sowing approach to examine colonization patterns of Melampyrum pratense, an annual myrmecochorous woodland herb, in a recent woodland area in NE Germany which lacks a natural population of the species. However, as it was not my purpose to add another research on myrmecochory to the existing literature, the transport of seed by ants was not studied here. The advantage of using an annual as a bioassay of plant dispersal ability is that plants reproduce and die in one growing season, so that several generations can be studied quickly (cf. Primack \& Miao 1992). The following questions were addressed: (1) How quickly does Melampyrum pratense colonize vacant sites, i.e. what are the mean and maximal migration rates? (2) Are there any differences in migration distances and colonization patterns between different habitats, and are migration rates constant during the buildup of the populations? (3) Is the observed dispersal facilitated by ants or by primary seed fall? (4) Which colonization patterns are realized in spreading populations? Moreover, I will discuss whether regional distributions of Melampyrum pratense may be limited by dispersal, and migration rates correlate with migration rates and dispersal distances of other myrmecochores.

\section{Material and methods The species}

The study was carried out with Melampyrum pratense L. (Scrophulariaceae), a common species in mixed oak and pine forests (Quercion roboris, Dicrano-Pinion) on acidic and nutrient-poor, sandy soils throughout northern Germany. However, as in several regions of Europe (cf. Hermy et al. 1999) here it is strongly associated with ancient woodland having existing least for 150 years (Heinken 1998). Limited dispersal is thought to be responsible for the species' extensive absence in secondary woodlands on former arable land, heath- or grassland.

Like all members of Melampyrum it is an annual hemiparasite, which apparently requires exclusively woody plants as hosts (Hegi 1974). In Central Europe Betula spp., Quercus spp. and Vaccinium spp. are particularly frequent hosts (Masselink 1980; Ter Borg 1985). Radicle germination takes place from late September until November, while green shoots emerge in the following April (Masselink 1980; Ter Borg 1985). In optimal conditions mature plants are characterized by long, horizontal lateral branches, the maximal height being about $20 \mathrm{~cm}$, and the maximal diameter about $50 \mathrm{~cm}$. In northeastern Germany Melampyrum pratense flowers from June to mid September and fruits from mid July to late September.

The seeds are few and large relative to those of other annuals. A maximum of four seeds are found in capsules which are strung on long spikes, most occurring on the horizontal branches. The mean number of viable seeds per plant is low (Salisbury 1942: 67, Masselink 1980: 40-75). Fresh seeds are ovoid 
with an apical elaiosome, 3-6 mm long and 1-2 mm wide, and dry weight ranges from 1.4 to $9.5 \mathrm{mg}$, with a mean $(\mathrm{n}=100)$ of $3.95 \mathrm{mg}$ (Salisbury 1942: $6.46 \mathrm{mg}$ ). They are attractive to ants (e.g. Formica rufa and Myrmica ruginodis) as the elaiosome contains a fatty substance (Masselink 1980), and the testa is rich in oil (Sernander 1906) and thus are readily taken and dispersed by them after being released from the capsules. The elaiosomes desiccate, moulder away or rapdily become detached. Although Thompson et al. (1997) regard Melampyrum pratense as forming a transient seed bank, a portion of the seeds is dormant for at least the first season, and may account for the presence of a substantial persistent seed bank (e.g. Masselink 1980). In own experiments the germination rate of seed from the "Lehnin" forest (see below) which were buried $5 \mathrm{~cm}$ deep in soil-filled plastic pots and overwintered outside did not diminish after one year, and some seed still germinated after three years.

Table 1. Characteristics of the study sites. ${ }^{1)}$ : Dominating species are indicated with bold-face. ${ }^{2)}$ : Examinations on 26 August 1999.

\begin{tabular}{|c|c|c|c|}
\hline Site/Population & M1 & M2 & M3 \\
\hline Topography & Hill top & Plain & Slope $\left(\mathrm{N}, 20^{\circ}\right)$ \\
\hline Soil moisture & Very dry & Dry & Dry \\
\hline \multicolumn{4}{|l|}{ Vegetation: } \\
\hline Tree layer ${ }^{1)}$ & $\begin{array}{c}\text { Quercus petraea (Mat- } \\
\text { tuschka) Liebl., Pinus } \\
\text { sylvestris L., Betula } \\
\text { pendula } \text { Roth. }\end{array}$ & $\begin{array}{l}\text { Quercus robur L., } \\
\text { Pinus sylvestris L. }\end{array}$ & $\begin{array}{l}\text { Betula pendula Roth, } \\
\text { Pinus sylvestris L., } \\
\text { Quercus robur L. }\end{array}$ \\
\hline Herb layer ${ }^{1)}$ & $\begin{array}{c}\text { Deschampsia flexuosa } \\
\text { (L.) P.B., Festuca ovina } \\
\text { L., Agrostis capillaris } \\
\text { L., Moehringia triner- } \\
\text { via (L.) Clairv. }\end{array}$ & $\begin{array}{c}\text { Deschampsia flexuosa } \\
\text { (L.) P.B., Festuca ovina } \\
\text { L. }\end{array}$ & $\begin{array}{c}\text { Deschampsia flexuosa } \\
\text { (L.) P.B., Calluna vul- } \\
\text { garis (L.) Hull, Carex } \\
\text { pilulifera L. }\end{array}$ \\
\hline Moss layer ${ }^{1)}$ & $\begin{array}{l}\text { Pleurozium schreberi } \\
\text { (Brid.) Mitt., Dicranum } \\
\text { scoparium Hedw. }\end{array}$ & $\begin{array}{c}\text { Pleurozium schreberi } \\
\text { (Brid.) Mitt., Bra- } \\
\text { chythecium sp. }\end{array}$ & $\begin{array}{c}\text { Pleurozium schreberi } \\
\text { (Brid.) Mitt., Dicranum } \\
\text { polysetum Sw. }\end{array}$ \\
\hline Herb layer cover & $25 \%$ & $45 \%$ & $60 \%$ \\
\hline Moss layer cover & $10 \%$ & $15 \%$ & $30 \%$ \\
\hline \multicolumn{4}{|l|}{ Occurring ant species: } \\
\hline $\begin{array}{l}\text { Colonies within the } \\
\text { study sites }(<5 \mathrm{~m} \text { be- } \\
\text { yond the sown plot })^{2)}\end{array}$ & $\begin{array}{l}\text { Formica fusca L., Lep- } \\
\text { tothorax sp., Myrmica } \\
\text { ruginoidis Nyl. }\end{array}$ & $\begin{array}{l}\text { Formica fusca L., Lep- } \\
\text { tothorax sp., Myrmica } \\
\text { rubra L. }\end{array}$ & $\begin{array}{l}\text { Formica fusca L., Lep- } \\
\text { tothorax sp., Myrmica } \\
\text { ruginodis Nyl. }\end{array}$ \\
\hline $\begin{array}{l}\text { Colonies close to the } \\
\text { study sites }{ }^{2)}\end{array}$ & $\begin{array}{l}\text { Formica rufa L. (50 m } \\
\text { SE) }\end{array}$ & $\begin{array}{l}\text { Formica rufa L. ( } 25 \mathrm{~m} \\
\text { NNW and } 10 \mathrm{~m} \mathrm{E} \text {, } \\
\text { worker ants foraging } \\
\text { within the site) }\end{array}$ & $\begin{array}{c}\text { Formica rufa L. (50 m } \\
\mathrm{W} \text { and } 30 \mathrm{~m} \mathrm{NE} \text {, worker } \\
\text { ants foraging within the } \\
\text { site) }\end{array}$ \\
\hline
\end{tabular}

\section{Study sites}

The location selected for the field study, "Glauer Berge", is situated in north-eastern Germany, approximately $20 \mathrm{~km} \mathrm{SSW}$ from the city boundary of Berlin. It is a terminal moraine of the Weichsel glacial with poor, acidic sands, predominantly covered by scots pine forests (Dicrano-Pinion), and in some places mixed oak forests (Quercion roboris, cf. Table 1). The soils are characterized by a rapid permeability and low water capacity; hill tops and south facing slopes are especially dry. The woodland area of the "Glauer Berge" is an isolated forest stand of approximately $3.5 \mathrm{~km}^{2}$ embedded in an agricultural landscape. Old land survey maps reveal that the forest was established by reforestation and natural succession on former grassland and arable land during the $19^{\text {th }}$ and the first half of the $20^{\text {th }}$ century. Natural populations of Melampyrum pratense are lacking completely, though it is common in some ancient 
woodlands nearby with similar edaphic conditions. I chose three sites with mixed oak forests, with varying topographies which appeared to be suitable to host populations of Melampyrum pratense in terms of environment because their substrate and vegetation was similar to habitats of natural populations. The characteristics of the sites including occurrences of seed-dispersing ant species are given in Table 1.

\section{Experimental procedures}

To establish the experimental populations I sow seeds of Melampyrum pratense into the three sites in the "Glauer Berge" forest on 16 October 1997. Seeds originated from the "Lehnin" forest, an ancient woodland with mixed oak forests approximately $25 \mathrm{~km} \mathrm{~W}$ of the "Glauer Berge" area. Each 100 randomly chosen, complete plants were collected from five sites in early September 1997. The plant material was combined and air-dried under ambient conditions for one week. All ripe seeds were shed from the capsules after this procedure. The seeds were then sorted out from the dried plant material, and each set of 300 seeds was sown in a $1 \times 1 \mathrm{~m}$ plot. Seeds were scattered evenly over the plots, and the litter and humus layer (consisting of scattered leaves plus a humus layer of $1-2 \mathrm{~cm}$ ) was then lightly raked to cover the seeds. This ensured that they settled to the soil surface.

Development of population size and colonization patterns following artificial introduction were investigated by recording the position of plants from 1998 through 2001 coming from the margins of the populations. The experimental sites were visited two times annually: In spring (15 May - 12 June) I examined the emerged seedlings, and in summer (24 July - 29 August) the sites were checked again for adult plants. In order to facilitate the localization of the plants a $20 \times 20 \mathrm{~m}$ permanent grid was laid out in the study sites around the sown plots using wooden poles and buried magnets. All the plant individuals were mapped exactly using a $1 \mathrm{x} 1 \mathrm{~m}$-frame subdivided in $10 \times 10 \mathrm{~cm}$ grids by strings. A wider area $(\mathrm{r}=50 \mathrm{~m})$ was checked for Melampyrum individuals. Any evidence of herbivory or fruit setting was noted.

An additional experiment was conducted in the "Lehnin" forest between 9 August and 1 September 1998 to examine seed fall pattern of Melampyrum pratense using adhesive cardboard (cf. Frey et al. 1999). A diaspore trap (consisting of cardboard covered with a self-adhesive plastic sheeting, $1.5 \times 1.5$ $\mathrm{m}$ ), was set around a single, robust, fruiting plant (height $15 \mathrm{~cm}$, diameter $40 \mathrm{~cm}$ ) within its natural habitat. As the released seeds become permanently adhered to the cardboard and thus cannot be removed by ants, the method allows a precise evaluation of primary dispersal.

Table 2. Climatic data for the experimental period (Potsdam weather station $15 \mathrm{~km} \mathrm{NNW}$ of the study site). ${ }^{1)}=$ precipitation / mean temperature $.^{2)}=$ humidity index (current year) / humidity index (19601990).

\begin{tabular}{lccccc}
\hline & $1961-1990$ & 1998 & 1999 & 2000 & 2001 \\
\hline $\begin{array}{l}\text { January - December: } \\
\quad \text { Precipitation [mm] }\end{array}$ & 590 & 596 & 406 & 538 & 626 \\
$\quad$ Mean Temperature $\left[{ }^{\circ} \mathrm{C}\right]$ & 8.7 & 9.4 & 10.2 & 10.4 & 9.3 \\
$\begin{array}{l}\text { May - September: } \\
\text { Precipitation [mm] }\end{array}$ & 331 & 301 & 192 & 316 & 405 \\
Mean temperature $\left[{ }^{\circ} \mathrm{C}\right]$ & 14.5 & 15.1 & 16.2 & 15.7 & 14.9 \\
$\begin{array}{l}\text { Humidity index }{ }^{1)} \\
\begin{array}{l}\text { Deviation of humidity index } \\
\text { from long-term index value }\end{array}\end{array}$ & 22.8 & 19.9 & 11.9 & 20.1 & 27.2 \\
\hline
\end{tabular}




\section{Climatic conditions for the experimental period}

Climatic data for the experimental period were provided by the Potsdam weather station (Table 2). Here precipitation is evenly distributed over the year, with a mean temperature of $-0.9{ }^{\circ} \mathrm{C}$ in January, and $17.9^{\circ} \mathrm{C}$ in July (1961-1990). The data regarding the vegetational period of Melampyrum pratense (April - September) reveal that all years studied were warmer than the long-term mean and that the years 1998-2000 were also drier. The vegetational period of 1999 had a very low precipitation in combination with high temperatures which resulted in extraordinarily dry climatic conditions (see humidity indices).

\section{Data analysis}

For each population and year, germinated and established Melampyrum pratense individuals were counted. I calculated rates of seedling establishment, and rates of annual increase of population size $\lambda$ (cf. Silvertown \& Charlesworth 2001) by counting the number of emerged seedlings in each year. The centre of each sown plot was ringed by a series of concentric circles each separated by $10 \mathrm{~cm}$. These circles were divided into 16 sectors radiating from the centre of the plot and corresponding with the compass directions (N, NNE, NE etc.).

Population area was calculated in two ways: (a) by counting the number of occupied 1 x $1 \mathrm{~m}$ permanent grids, and (b) by estimating the perimeter of the population. For this, the distance of the outermost germinated individual in each sector to the centre was determined. In order to make the graphical interpretation easier the position of this individual was projected on the line bisecting the sector, and then all points on these bisecting lines were joined up. A number of 16 sectors appeared to be a good compromise: when choosing a finer partition (32, 64 or more), the perimeter was rather irregular and difficult to interpret, when applying too a coarse division, single outlier-individuals resulted in an overestimation of the population area. Rate of increase of population area was determined as for population size.

Migration rates (= migration distances per year) were defined for each sector by calculating the distance between the projections to the bisector of the angle of the farthest individuals in subsequent years. Mean migration rates were calculated for each population and each studied year, and for all data. To test differences between medians of the populations and the years, a Kruskal-Wallis test was used (Lozan 1992). Where differences occurred, a Nemenyi test was additionally performed to separate the mean of the ranges, with a significance level of 5\%. Kruskal-Wallis test was also performed to test differences in migration rates between directions. A trend-line was fitted to the frequency distribution of migration rates using with Microsoft Excel 2000.

To evaluate spatial distribution of emerged seedlings, the number and density of plants in all populations was correlated with their distance from the centre of the sown plot. The data of the pooled distances (10-cm-concentric circles) resulted in histograms of frequency distributions. Advancing populations showed a significant decrease between the observed maximal individual number and abundance distance, respectively, and the farthest individual. Linear, exponential or logarithmic trend-lines were then fitted to the relationship of the advancing edge with Microsoft Excel 2000, and this derived a colonization model for Melampyrum pratense (cf. Matlack 1994; Brunet \& Oheimb 1998; Bossuyt et al. 1999; Honnay et al 1999).

\section{Results}

\section{Seed fall pattern}

The seed shadow of a robust Melampyrum pratense individual with max. $25 \mathrm{~cm}$ long lateral branches within its natural habitat is shown in Figure 1. It indicates a maximum seed density between 4 and 18 $\mathrm{cm}$, and a very short tail beyond the maximum range. The highest dispersal distance was only $25 \mathrm{~cm}$, and the lowest $3 \mathrm{~cm}$. The medium distance of seeds from the stem axis of the parental plant was only $14.6 \pm$ SD $5.3 \mathrm{~cm}(\mathrm{n}=58)$, the dispersal distances follow a Gaussian distribution $\left(\chi^{2}\right.$-test, $\left.\mathrm{p}<0.001\right)$. 


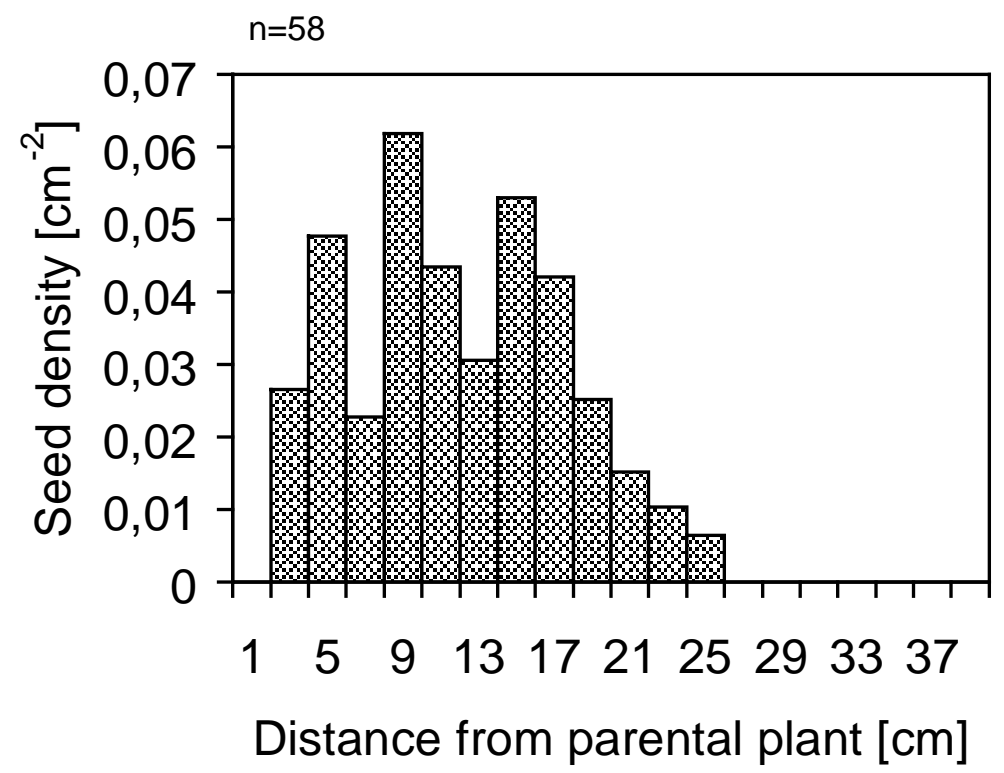

Figure 1. Frequency distribution of the seed fall distances of a Melampyrum pratense individual, detected by adhesive cardboard.

Table 3. Development of Melampyrum pratense populations resulting from seed sown $(\mathrm{n}=300)$ in 1997 at the three study sites in the "Glauer Berge" woodland. ${ }^{1)}$ : Formation of cotyledons (spring control). ${ }^{2)}$ : Flowering and usually fruiting (summer control). ${ }^{3)}$ : Germinated individuals.

\begin{tabular}{|c|c|c|c|c|c|}
\hline Year & & 1998 & 1999 & 2000 & 2001 \\
\hline \multirow[t]{5}{*}{ M1 } & Germinated individuals ${ }^{1)}$ & 39 & 487 & 222 & 535 \\
\hline & Established $[\%]^{2)}$ & 79.5 & 76.6 & 64.4 & 84.3 \\
\hline & Annual rate of increase $(\lambda)^{3)}$ & & 12.49 & 0.46 & 2.41 \\
\hline & Herbivory & - & - & + & \pm \\
\hline & Fruit setting & + & - & \pm & + \\
\hline \multirow[t]{5}{*}{ M2 } & Germinated individuals ${ }^{1)}$ & 31 & 87 & 292 & 1044 \\
\hline & Established [\%] ${ }^{2)}$ & 77.4 & 90.8 & 77.7 & 71.6 \\
\hline & Annual rate of increase $(\lambda)^{3)}$ & & 2.81 & 3.36 & 3.58 \\
\hline & Herbivory & - & + & - & - \\
\hline & Fruit setting & + & \pm & + & + \\
\hline \multirow[t]{5}{*}{ M3 } & Germinated individuals ${ }^{1)}$ & 35 & 260 & 423 & 1811 \\
\hline & Established $[\%]^{2)}$ & 82.9 & 83.5 & 80.6 & 69.7 \\
\hline & Annual rate of increase $(\lambda)^{3)}$ & & 7.43 & 1.63 & 4.28 \\
\hline & Herbivory & - & \pm & \pm & - \\
\hline & Fruit setting & + & + & + & + \\
\hline \multirow[t]{3}{*}{$\Sigma \mathrm{M} 1-3$} & Germinated individuals ${ }^{1)}$ & 105 & 834 & 937 & 3390 \\
\hline & Established $[\%]^{2)}$ & 80.0 & 80.2 & 76.6 & 72.6 \\
\hline & Annual rate of increase $(\lambda)^{3)}$ & & 7.94 & 1.12 & 3.62 \\
\hline
\end{tabular}




\section{Development of the experimental populations \\ Individual number and establishment of seedlings}

All seed sowing experiments resulted in the recruitment of Melampyrum pratense populations at the unoccupied sites, which survived up to the fourth season. In 1998, between 31 and 39 individuals germinated in each population, i.e. 10.3\%-13\% of the seeds sown in autumn 1997 (Table 3). In the following year populations increased in all study sites, but to a different extent: While M1 was more than ten fold larger in 1999 as in the preceding year and thus exhibited an extreme increase, M2 only trebled, and M3 displayed an intermediate growth. However, M1 diminished strongly in 2000, but a further powerful population growth was recorded for M2 and M3. As in 1999, in 2001 all three populations increased again to a large extent. Considering all populations (M1-M3) as a whole reveals that there was a continuous growth in individual number during all three years after establishment in 1998, but it was much smaller in 2000 than in 1999 and 2001. Altogether, population increase after four years was maximal in M3 $(\mathrm{n}=1811)$, medium in M2 $(\mathrm{n}=1044)$ and minimal in M1 $(\mathrm{n}=535)$. As the population size (germinated individuals) of M2 approximately trebled each year (cf. Table 3), the data suggests an exponential rate of natural population increase $\left(r_{m}=8.949 * e^{1.176 x}, R^{2}=0.998\right)$. In M1 and M2, population increase varied too strong between the investigated years to fit a model to the data, and the growth term was maximal in the first year after establishment.

Most of the Melampyrum pratense plants which germinated in spring developed into adult plants. The rate of seedling establishment probability varied between $64.4 \%$ and $90.8 \%$ (Table 3), but there were no clear differences between the years or populations. Some populations were negatively affected by herbivory. In 1999 large quantities of plants of M2, and in 2000 of M1 were bitten off down to the basis of the stem axis, so that they were unable to set fruit. However, fruit setting was also very low in 1999 on the very dry site of M1. Here, many Melampyrum individuals dried up before fruit ripened, due to the extremely dry climatic conditions of the year (see Table 2).

\section{Population area and shape}

In 1998 all, or nearly all, Melampyrum pratense seeds germinated within the sown plots (Table 4, Figure 2). In the following years, large amounts of seed were dispersed beyond the sown plots. Thus, both the number of germinated plants beyond the sown plots, as well as their proportion related to the total number of plants, increased continuously (Table 4) with few exceptions.

Table 4. Melampyrum pratense individuals beyond the sown plots in the populations resulting from seed sown in 1997 at the three study sites in the "Glauer Berge". ${ }^{1)}$ : Formation of cotyledons (spring control).

\begin{tabular}{llcccc}
\hline Year & & 1998 & 1999 & 2000 & 2001 \\
\hline M1 & Germinated individuals ${ }^{1)}$ & 0 & 262 & 202 & 479 \\
& Portion of the total number [\%] & 0 & 53.8 & 91.0 & 89.5 \\
M2 & Germinated individuals ${ }^{1)}$ & 1 & 55 & 241 & 944 \\
& Portion of the total number [\%] $^{*}$ M3 & 3.2 & 63.2 & 82.5 & 90.4 \\
& Germinated individuals ${ }^{1)}$ & 1 & 68 & 245 & 1250 \\
\multirow{2}{*}{$\Sigma$ M1-3 } & Portion of the total number [\%] & 2.9 & 26.2 & 57.9 & 69.0 \\
& Germinated individuals ${ }^{1)}$ & 2 & 385 & 688 & 2673 \\
& Portion of the total number [\%] & 1.9 & 46.2 & 73.4 & 78.8 \\
\hline
\end{tabular}




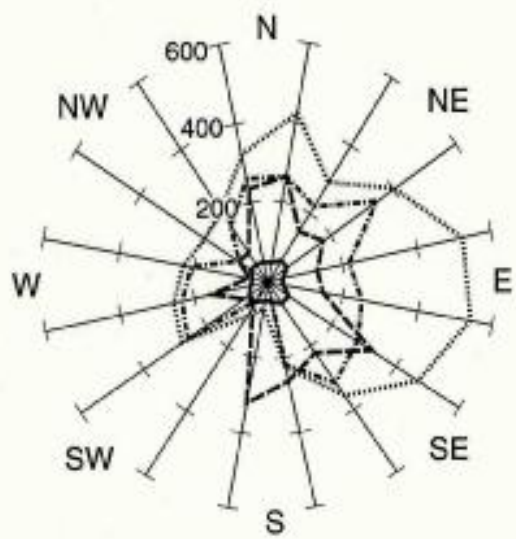

M1

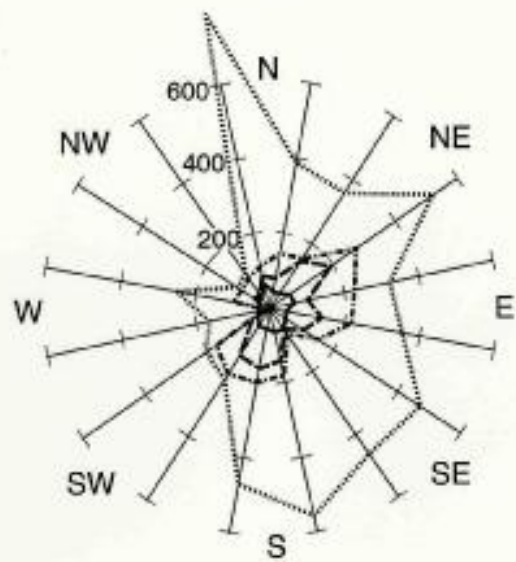

M2

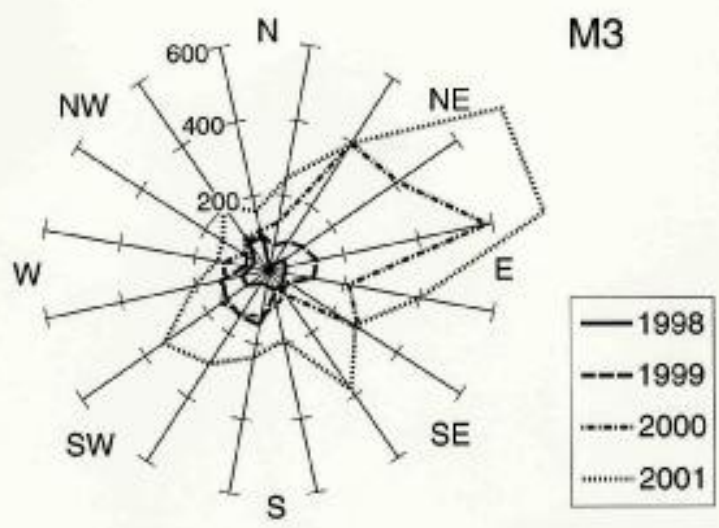

Figure 2. Development of Melampyrum pratense population areas resulting from seed sown in 1997 at the three study sites in the "Glauer Berge" woodland, delineated by connecting of the farthest individuals in 16 directional sectors.

As for individual numbers, the area of all populations has increased each year, from less than $1 \mathrm{~m}^{2}$ in 1998 up to more than $30 \mathrm{~m}^{2}$ in 2001 (Table 5, Figure 2). While from 1997-1999 the areas calculated by the occupied $1 \times 1 \mathrm{~m}$ grids are much larger than those obtained from the linkage of the farthest individuals in 16 sectors and thus may be overestimated, in 2001, when the population areas were larger, the results do not deviate significantly. In contrast to the individual numbers, after three years of dispersal, the occupied areas were rather similar in the three populations. The rates of increase of population area, calculated by linkage of the farthest individuals in 16 sectors, varied considerably between the years (Table 5) in all populations, thus no model describes the increase over the experimental period. However, with the exception of M2 the growth term was again maximal in the first year. Though the rates of increase of the population size and of the population area were not exactly in accordance with each other (cf. Table 3, 5), there was an obvious relationship between them, which is described by a linear regression (Figure 3). The similar rates of increase of individual number and population area 
shown by the regression suggest that population densities remained more or less constant during the investigation period.

Table 5. Development of Melampyrum pratense population areas resulting from seed sown in 1997 at the three study sites in the "Glauer Berge" woodland. (a) occupied 1 x 1 m grids; (b) calculated by linkage of the farthest individuals in 16 directional sectors (cf. Fig. 2, 3).

\begin{tabular}{llcccc}
\hline Year & & 1998 & 1999 & 2000 & 2001 \\
\hline M1 & Population area $\left[\mathrm{m}^{2}\right]$ (a) & 1 & 21 & 26 & 38 \\
& Population area $\left[\mathrm{m}^{2}\right]$ (b) & 0.77 & 9.98 & 14.84 & 33.06 \\
& Annual rate of increase (b) & & 12.96 & 1.49 & 2.23 \\
\multirow{2}{*}{ M2 } & Population area $\left[\mathrm{m}^{2}\right]$ (a) & 2 & 9 & 13 & 40 \\
& Population area $\left[\mathrm{m}^{2}\right]$ (b) & 0.72 & 3.18 & 6.92 & 40.84 \\
& Annual rate of increase (b) & & 4.42 & 2.18 & 5.90 \\
M3 & Population area $\left[\mathrm{m}^{2}\right]$ (a) & 2 & 8 & 22 & 42 \\
& Population area $\left[\mathrm{m}^{2}\right]$ (b) & 0.58 & 2.89 & 14.07 & 35.14 \\
& Annual rate of increase (b) & & 4.98 & 4.87 & 2.50 \\
\multirow{2}{*}{ M1-3 } & Population area $\left[\mathrm{m}^{2}\right]$ (a) & 5 & 38 & 61 & 119 \\
& Population area $\left[\mathrm{m}^{2}\right]$ (b) & 2.07 & 16.05 & 35.38 & 109.04 \\
& Annual rate of increase (b) & & 7.75 & 2.20 & 3.08 \\
\hline
\end{tabular}

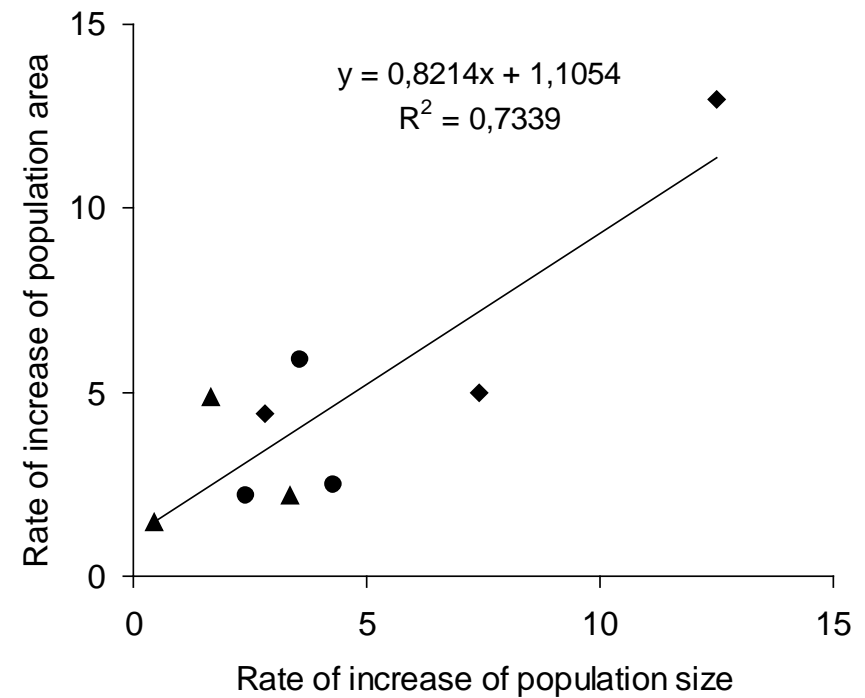

Figure 3. Relationship between annual increase of population size and population area of Melampyrum pratense populations resulting from seed sown in 1997 at the three study sites in the "Glauer Berge" woodland. $\bullet:$ 1999; 5 : 2000; •: 2001.

However, the shape of the population areas differed strongly (Figure 2): Taking the situation in 2001, M1 enlarged mainly to the east, M2 to the north, north-east and south, and M3 to the north-east. In 2001, i.e. after three years of dispersal, the farthest Melampyrum pratense individual was only 5.44 $\mathrm{m}$ from the centre of the sown plot in M1, $7.63 \mathrm{~m}$ in M2 and $7.22 \mathrm{~m}$ in M3. Within the 16 sectors, the shortest distances of the farthest individuals in 2001 were only $0.67 \mathrm{~m}$ for M1, $1.03 \mathrm{~m}$ for M2, and 1.34 $\mathrm{m}$ for M3 (cf. Figure 2). In most sectors, a continuous spread of Melampyrum beyond last year's position was recorded. However, in some cases a retreat occurred, i.e. newly colonized areas were not occu- 
pied the following year (e.g. M1: $1999 \rightarrow 2000 \mathrm{~S}$ of the sown plot). Additionally, in M3 also a remarkable spread of approximately 2-3 $\mathrm{m}$ in all southerly directions, i.e. steeply inclined slope occurred.

Figure 4 shows the development of an "ideal" population area, delineated by linkage of the medium positions of the farthest individuals in 16 sectors of the three study sites. It elucidates, that on average the spread of the three Melampyrum pratense populations was maximal from north-east to south-east, and minimal from south to north-west. However, it is also shown that, on average, spread may be circular (see below).

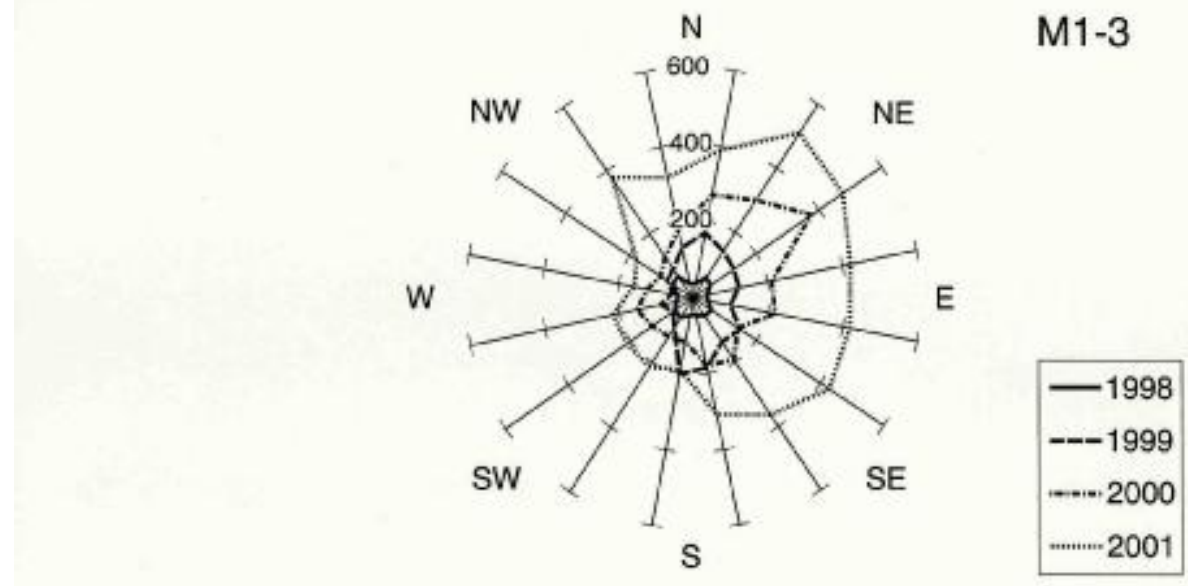

Figure 4. Development of an "ideal" Melampyrum pratense population area resulting from seed sown in 1997 in the "Glauer Berge" woodland, delineated by connecting of the medium positions of the farthest individuals in 16 directional sectors of the three study sites.

\section{Migration rates}

The mean yearly migration distance of Melampyrum pratense populations calculated for all three years when seeds were dispersed within the 16 sectors was $91 \mathrm{~cm}(\mathrm{n}=144)$. The highest migration rate observed was $648 \mathrm{~cm}$, and the lowest (retreat in M1, see above) was $-322 \mathrm{~cm}$. However, the distribution of migration rates (Figure 5) elucidates that both large distances $(>2 \mathrm{~m})$ and retreats are rare events (14\% and $8 \%$, respectively). Thus, $78 \%$ of the observations concerned migration rates between $0-200 \mathrm{~cm}$, and $59 \%$ between 0 and $100 \mathrm{~cm}$. Regarding distances $>0 \mathrm{~cm}$ (92\% of observations), distribution of migration rates clearly follows a negative exponential model.

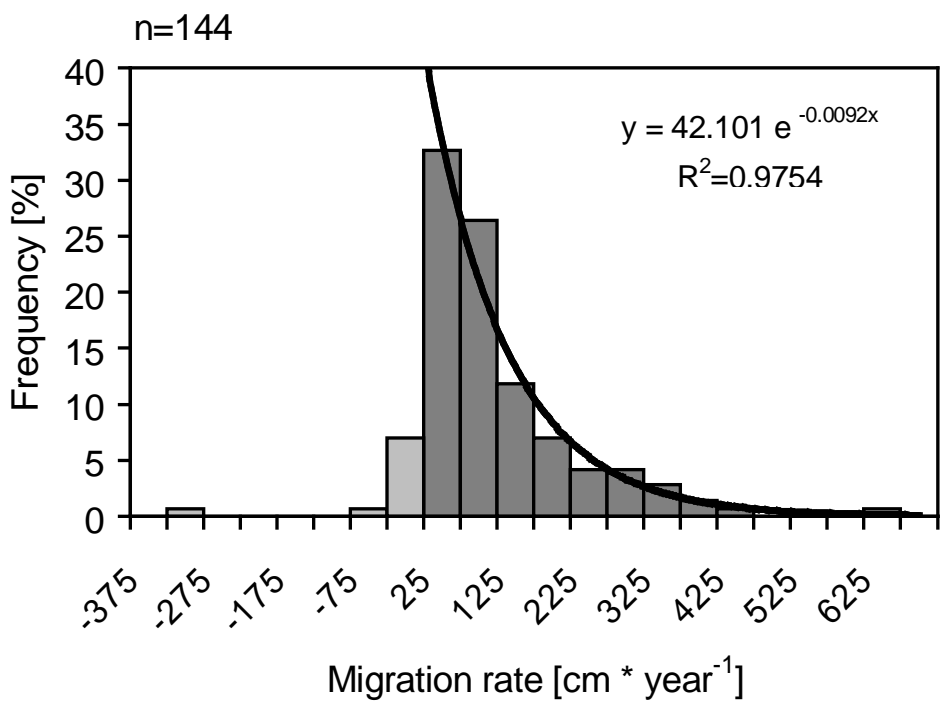

Figure 5. Histogram of yearly migration distances of Melampyrum pratense populations resulting from seed sown in 1997 at the three study sites in the "Glauer Berge" woodland, calculated for 1998-2001 by the differences between the distances of the farthest individuals in 16 directional sectors. 
According to the development of population areas until 2001, the mean migration rate in all the years studied was higher in M2 than in M1 and M3, but there was no significant difference between the populations (Table 6). Nevertheless, the mean migration rate of all three populations was significantly higher from 2000 to 2001 as compared to the first two years of dispersal. This is especially true for M2, but in M3 there is also an obvious tendency of increasing of migration rates from $1998 \rightarrow 1999$ to $2000 \rightarrow 2001$ (cf. Table 6). In M1, the extraordinarily high migration rate of $1998 \rightarrow 1999$ is linked with an equivalent increase in individual number, and the low mean distance of $1999 \rightarrow 2000$ is coupled with the evident decrease of the population (cf. Table 3 ). Migration rate was not regularly distributed over all directions (cf. Figure 2, 4): Using eight directions (N, NE, E and so on) the highest mean migration rates were found in eastern (NE: $164 \mathrm{~cm}$ ), and the lowest in south-western directions (W: $63 \mathrm{~cm}$ ). However, there were no significant differences between the eight directions both over all three years of dispersal and in each year (Kruskal-Wallis test; $\mathrm{H}, \mathrm{df}=7$ ), suggesting that dispersal direction has no influence on migration rate.

Table 6. Mean migration rates $\left[\mathrm{cm}^{*}\right.$ year $\left.^{-1}\right]$ of Melampyrum pratense populations resulting from seed sown in 1997 in the "Glauer Berge" woodland, calculated by the differences between the distances of the farthest individuals in 16 directional sectors. Differences between medians of the three populations and the studied years (bold-face) were tested with Kruskal-Wallis one-way ANOVA ( $\mathrm{H}, \mathrm{df}=2)$ and subsequent Nemenyi test. $* *$ : $\mathrm{p}<0.01$; all other differences: non significant $(\mathrm{p}>0.05)$.

\begin{tabular}{lccccc}
\hline & $1998 \rightarrow 1999$ & $1999 \rightarrow 2000$ & $2000 \rightarrow 2001$ & $\mathbf{1 9 9 8 - 2 0 0 1}$ & Min./Max. \\
\hline M1 & 121 & 39 & 94 & $\mathbf{8 5}$ & $-322 / 302$ \\
M2 & 46 & 54 & 205 & $\mathbf{1 0 2}$ & $-53 / 648$ \\
M3 & 48 & 93 & 120 & $\mathbf{8 7}$ & $-9 / 441$ \\
M1-3 & $\mathbf{7 1}$ & $\mathbf{6 2}$ & $\mathbf{1 4 0 * *}$ & 91 & \\
Min./Max. & $-53 / 274$ & $-322 / 441$ & $-2 / 648$ & & $-322 / 648$ \\
\hline
\end{tabular}

\section{Colonization patterns}

Only in 1998 the germinated Melampyrum pratense individuals were scattered more or less regularly over the quadratic sown plots. From 1999 onward the centres of the populations (i.e. the area of, or immediately around, the sown plots) were, without exception, more densely populated than their margins, of which most were characterized by only few scattered individuals. In M1 and M3 Melampyrum individuals were often obviously accumulated near inhabited ant colonies of Formica fusca and Myrmica ruginodis. Regarding both the number of individuals and the population density (plants per $\mathrm{m}^{2}$ ) dependent of the distance from the centre of the sown plot reveals a more ore less continuous decrease of abundance with increasing distance between the observed maximum and the farthest individual. While M1 exhibits unimodal colonization distance histograms (with a second maximum between 1 and $2 \mathrm{~m})$ symbolizing patchy distributions from 1999 through 2001, M2 and M3 typically exhibited monotonic curves.

Distance frequency distributions of all three populations representing an "ideal" population are shown in Figure 6. Plotting the number of individuals against the distance from the centre of the sown plots reveals an unimodal pattern in 1999 resulted from the distribution of M1, and negative logarithmic distributions (best fit) for 2000 and 2001. As expected, no "advancing edge" developed in 1998. Plotting the population density against the distance reveals that the maximal density was, without exception, in or nearby the centre of the sown plot, and decreases steeply with greater distance. Here, best fits were negative exponential. Histograms indicate that the population density in the sown plot increased after 1998 (cf. Table 4). In 1999 and 2001 average densities $>200$ individuals were recorded at the population centre, but there was a decrease in 2000 (especially caused by M1, cf. Table 3, 4). Figure 6 also elucidates that from 1998 to 2001 not only the edges of the populations, but also the regions of high abundances, advanced continuously from the sown plots. A relatively high population density, i.e. a mean abundance of at least 10 Melampyrum individuals per $\mathrm{m}^{2}$, occurs in the first $60 \mathrm{~cm}$ from the centre of the sown plot in 1998, $90 \mathrm{~cm}$ in 1999, $150 \mathrm{~cm}$ in 2000, and $240 \mathrm{~cm}$ in 2001 (arrows in Figure 6). 
Thus, the migration of the high-abundance-area was much slower than of the advancing edge $(83 \mathrm{~cm}$, $322 \mathrm{~cm}, 564 \mathrm{~cm}, 763 \mathrm{~cm}$ ), but also obviously accelerating in the three years of dispersal.
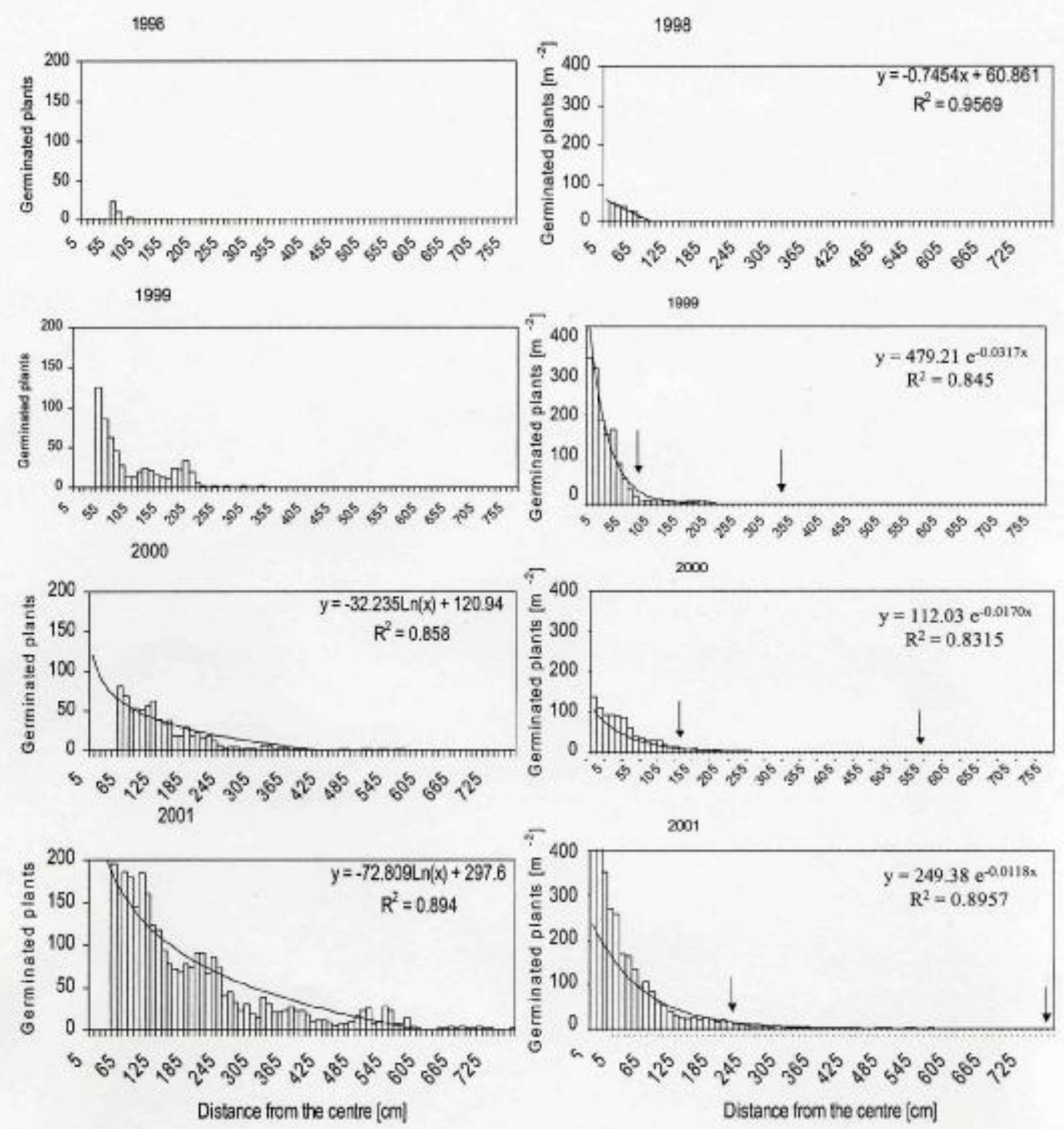

Figure 6. Colonization distance frequency distributions of the migration fronts and associated curves (best fit) of Melampyrum pratense populations M1-3, resulting from seed sown in 1997 at the three study sites in the "Glauer Berge" woodland (mean of the three populations). Left column: number of individuals plotted. Right column: population density plotted; arrows (left): outer diameter of population density $>10$ individuals $* \mathrm{~m}^{-2}$; arrows (right): farthest individual.

\section{Discussion}

\section{Seed fall pattern}

The observed seed fall pattern indicates that seeds of Melampyrum pratense fall within a very small distance from the parental plant, i.e. they simply drop from the capsules ("barochory") of which most are strung on the long, horizontal lateral branches. This occurs, as seeds are heavy and have no features supporting wind dispersal, and both seed exposition height and wind velocities within forests are low. The distribution of the seed shadow indicates a very steep decline of seed fall beyond its maximum. Thus, dispersal distances larger than $25 \mathrm{~cm}$ are extremely unlikely (cf. Winkler \& Matthies 2001 for Melampyrum arvense). Contrary to Melampyrum pratense, seed shadows usually exhibit a long tail with a few seeds dispersed over longer distances beyond their maximum (e.g. Harper 1977; Willson 1993). Though the results of the experiment may not be exactly representative for the assesment of primary dispersal, it indicates that dispersal by barochory is hardly related to local colonization of Melampyrum pratense. 


\section{Development of the experimental populations Establishment of populations}

As all sowing of seed resulted in recruitment of populations which survived and expanded into the new habitat up to the fourth year, the study sites appear to be suitable for Melampyrum pratense. Already, after three years, all populations were larger than 100 individuals which Winkler \& Matthies (2001) presume to be critical for long-term survival of the related species Melampyrum arvense L. Thus, my results demonstrate that altered soil characteristics resulting from deforestation in the past (e.g. Verheyen et al. 1999) are not responsible for the lack of natural Melampyrum pratense populations in the "Glauer Berge" woodland. This, and the low migration distances, stress the importance of seed dispersal limitation for the regional distribution of Melampyrum pratense, i.e. the absence in the study area and presumably in many other secondary woodland areas in northern Germany. This has been demonstrated for several other European forest herbs by sowing seed (Ehrlén \& Eriksson 2000) or by implantations (Petersen \& Phillip 2001) in unoccupied sites.

\section{Individual number and seedling establishment}

In my experiment the germination of Melampyrum pratense seeds in 1998 was obviously higher than in a natural population studied by Masselink (1980) in the Netherlands, where only 3.9\% of the produced seeds germinated in the following spring. This difference may be attributed mainly to a lower predatory activity in my experiment, as most seeds were covered by litter and humus, but may also be explained by a different position of my study sites within the distribution area of Melampyrum pratense. Without exception a high proportion of seedlings similar to Masselink's population also became adult plants. Neither climatic conditions during the experimental period, nor environmental conditions like soil moisture, or plant species composition (cf. Table 1), had an obvious influence on seedling establishment.

However, population increase differed strongly between the three populations and was minimal on the driest study site of M1. Here, the rapid decrease in individual number from 1999 to 2000 was probably caused by the extreme drought in 1999. It negatively affected the seed production, because many individuals dried out before fruit ripened and most of the remainder were smaller than usual. Also the low rate of increase at the more moist site M3 may have resulted from the drought in 1999. The extinction of M1 during a sequence of very dry vegetational periods appears to be possible, but regeneration from the seed bank may support survival of Melampyrum pratense in these rare cases (cf. Masselink 1980). In contrast to the climatic conditions, the influence of herbivory on seed production and individual number of the experimental populations seemed to be negligible, presumably as herbivory affected only a limited number of individuals.

Only M2, which was obviously not affected by drought in 1999, exhibited an exponential growth term during the experimental period, i.e. a constant rate of annual increase in individual number each year. For the other populations, the maximal growth term in the first year after establishment suggests a generally decreasing annual rate of increase. This corresponds with the statement of Harper (1977) that few plant populations - unlike algae, duckweeds, or water ferns - exhibit exponential growth, because their fixed root habit prevents them from moving out of limited resources and escaping from their neighbours. The result is that members in the centre of a population are under a density stress hindering development even though unexploited resources are present nearby (cf. Figure 6). Thus, the geometric progression of M2 will likewise not continue indefinitely.

\section{Dispersal vectors}

Ants are presumed to be chiefly responsible for seed removal which enabled the spread of the experimental Melampyrum pratense populations into the new habitats. They were present at all study sites; plant individuals were sometimes accumulated around inhabited ant nests; and the seed fall patterns (see Figure 1) were unable to account for the observed migration distances. All Myrmica and Formica species occurring at the study sites (see Table 1) have been reported to be commonly involved in myrmecochory in northern temperate forests (e.g. Beattie 1983; Kjellsson 1985; Ohara \& Higashi 1987; Gibson 1993); transport of Melampyrum pratense seeds has been documented for Formica rufa and Myrmica ruginodis (Sernander 1906). Also Leptothorax spp. are sometimes involved in dispersal mutualisms (Beattie 1983; Gorb \& Gorb 1999a), but they may be too small to transport the large Melampyrum seeds (cf. Higashi et al. 1989 for Trillium tschoskii). However, with my approach it is not possible 
to exclude additional dispersal vectors. For example, small rodents consume Melampyrum seeds in great numbers (e.g. Masselink 1980) and sometimes transport them to their storerooms (Matthies 1991).

Usually ants pick up seeds and carry them into their nests, where the elaiosomes are nibbled off (e.g. Sernander 1906). Subsequently, a varying proportion of seed is discarded around the nest or at territory borders (e.g. Ohkawara et al. 1996, Gorb \& Gorb 1999b). Additionally many seeds are dropped on the way to the nest (Gorb \& Gorb 1999b). Only fresh seeds with intact elaiosomes are attractive for ants (e.g. Kjellsson 1985; Oostermeijer 1989). As the Melampyrum seeds sown in 1997 were stored over weeks, the elaiosomes were dessicated or detached, and the seeds were thus not dispersed in the autumn of 1997. However, in the following years a large proportion of seed was obviously detected and transported.

Dispersal distances of myrmecochorous seeds are dependent on the size of the involved ant species. Small species usually have high nest densities with small foraging territories and thus transport seeds only short distances (e.g. Pudlo et al. 1980; Gorb \& Gorb 1999a,b). The relatively low migration distances of Melampyrum pratense indicate that, especially Formica fusca and Myrmica spp., i.e. ant species of medium size with foraging territories of only few square metres, may be responsible for seed dispersal in my experiment. The role of Formica rufa, a large species with large colonies and foraging territories, may be low, as there were no plant individuals near Formica rufa colonies although worker ants were foraging frequently within the M2 and M3 populations. However, the rapid migration of M2 to NNW in 2001 and of M3 to NE from 2000 onward (Figure 2) was in the direction of Formica rufa colonies (cf. Table 1) and thus may be caused by their activity.

\section{Migration rates and population areas}

In the current study yearly migration distances of $<1 \mathrm{~m}$ predominated, and no seed was dispersed further than a few metres by ants. These findings correspond well with the dispersal distances of other myrmecochorous herbs in northern hemispheric temperate woodlands. Mean distances derived from field studies in North America (Culver \& Beattie 1978; Pudlo et al. 1980; Gibson 1993; Heithaus 1986; Cain et al. 1998; Kalisz et al. 1999), Europe (Kjellsson 1985) and Japan (Ohara \& Higashi 1987; Higashi et al. 1989; Ohkawara \& Higashi 1994; Ohkawara et al. 1996) range from $0.28 \mathrm{~m}$ for Viola selkirkii (Ohkawara \& Higashi 1994) to 3.09 m for Sanguinaria canadensis (Pudlo et al. 1980). For all the 14 temperate forest species studied the mean dispersal distance is $0.94 \mathrm{~m}$ and thus very similar to the mean migration rate of Melampyrum pratense. For Melampyrum lineare Gibson (1993) found a mean dispersal distance of $1.08 \mathrm{~m}$. Most seeds are usually transported very short distances by ants, while few seeds reach longer distances of up to a few metres (e.g. Higashi et al. 1989; Ohkawara \& Higashi 1994; Kalisz et al. 1999). Melampyrum lineare seeds were transported a maximal $4.45 \mathrm{~m}$, but $80 \%$ were dispersed within $1.5 \mathrm{~m}$ (Gibson 1993). My study confirms that maximal myrmecochorous dispersal distances of several decades as recorded by Cain et al. (1998: $35 \mathrm{~m}$ for Asarum canadense) are rare events, and maximal distances of $70 \mathrm{~m}$ as recorded by Sernander (1906: Melica nutans and Viola hirta) are questionable or very exceptional observations.

The obvious differences in population areas and shapes among the investigated Melampyrum pratense populations may especially be caused by differences in the distribution of ant nests. In several studies it was shown that the dispersal patterns of seeds are influenced strongly by nest density and distribution, population size and territoriality of seed dispersing ants (e.g. Kjellsson 1985; Gorb \& Gorb 1999b). For example, high nest densities imply small dispersal distances (Gibson 1993), but removal rate of seeds may be increased because of small distances from food sources to nests (cf. Kjellsson 1985; Higashi et al. 1989). Removal rate is also dependent on density and species composition of seeds around the ant nests (e.g. Heithaus 1986; Oostermeijer 1989; Smith et al. 1989). Additionally, the distribution of plant individuals does not only depend on the distribution of seeds, but also on different rates of recruitment at different microsites. The overall sparse colonization in the southern part of M1 is probably caused by a layered leaf litter and low light intensities under a Quercus petraea shrub which is an unfavourable microsite for Melampyrum pratense (cf. Masselink 1980).

Contrary to distribution of ant nests and vegetational differences, topographic factors and the direction did not obviously influence migration rates and population shapes, as migration also occurred more or less evenly in all directions, and seeds were dispersed both up and down hill in M3. This happened because myrmecochorous dispersal direction depends on the relative positions of seeds and ant nests 
(Higashi et al. 1989; Ohkawara et al. 1996; Kalisz et al. 1999), which are randomly distributed between several plant populations.

Migration rates were not constant throughout the experimental period, but rose with population size and increase, respectively, from $1998 \rightarrow 1999$ to $2000 \rightarrow 2001$. This happened because the maximum seed dispersal distance is strongly dependent on the amount of seeds produced (cf. Petersen \& Philipp 2001), i.e. a larger number of dispersed seeds implies a higher probability that some are dispersed over longer distances. Invading organisms may spread as "travelling waves" proceeding with a constant velocity, or as "dispersive waves" with a continuously increasing velocity (e.g. Shigesada \& Kawasaki 1997). Similarly to several other experiments, from my data it is difficult to distinguish between the increasing migration rate of a travelling wave during the build-up phase of the population, and the continuously increasing migration rate of a dispersive wave because of the short monitoring period (cf. Frantzen \& van den Bosch 2000). After Kot et al. (1996) the spread will be a travelling wave, if the tail of the probability density function describing the dispersal distances of all offspring, falls off faster than, or equally fast as, an exponential function. If the tail falls off slower, the resulting wave will be dispersive. As all distributions for M1-3 (Figure 6) fall off equally or faster than an exponential function, my data suggest a travelling wave for the spread of Melampyrum pratense. However, it remains unclear, whether the migration rate of 2001 is the end of the build-up phase or will increase over more years.

The migration rates found for Melampyrum pratense do not only correspond well with the dispersal distances, but also with the migration rates of other myrmecochorous woodland herbs in temperate forests, which were calculated on the basis of plant distributions across ecotones between ancient and recent woods (occurrence of the farthest individual). Matlack (1994) found mean migration rates of 1.13 $\mathrm{m}_{\text {year }}{ }^{-1}$ in eastern North America; Brunet \& Oheimb (1998) $0.52 \mathrm{~m}$ in southern Sweden, Bossuyt et al. (1999) and Honnay et al. (1999) $0.52 \mathrm{~m}$ in Belgium, and Dzwonko (2001) $0.54 \mathrm{~m}$ in Poland. Altogether, the mean migration rates varied between 0 and $2.28 \mathrm{~m}$ year $^{-1}$, the average being $0.65 \mathrm{~m}_{\text {year }}{ }^{-1}$ for 30 ant-dispersed species. However, migration rates of these studies cannot be easily compared with my results. Potential migration of many species may have been underestimated, because several were recorded in the farthest plots of a site, and colonization of recent woodlands might not have started from the nearest part of the ancient forest populations (Brunet \& Oheimb 1998). Moreover, colonization capacity in young secondary forests may be reduced, because site characteristics such as soil conditions and canopy cover differing from old-growth forests negatively affect recruitment of species (Honnay et al. 1999; Brunet et al. 2000; Verheyen \& Hermy 2001b). Finally, most of the woodland herbs investigated were perennial, clonal species. As the majority take 2-4 yrs until the first seed is set (cf. Petersen \& Philipp 2001), migration rates are lower than dispersal distances for these species. Instead they exhibit a considerable lateral spread by clonal growth (cf. Brunet \& Oheimb 1998; Petersen \& Philipp 2001).

\section{Colonization patterns}

Seed dispersal curves, unlike colonization curves, are well characterized. They usually have a peak, with a majority of seeds deposited relatively close to the parental plant. Beyond this peak, the number of dispersed seeds decreases monotonically with the distance from the mother plant (e.g. Willson 1993). In most cases these "tails" are best described as negative exponential functions (e.g. Harper 1977; Willson 1993). Colonization of Melampyrum pratense was also characterized by an even and marked decreasing population density with the distance from the sown plot, while the "colonizing front" advanced continuously outward (Figure 6). Colonization patterns of the unoccupied habitats were negative exponential with respect to density. This indicates that, regarding all three populations, seeds were more or less randomly dispersed despite the observed accumulation of plants around inhabited ant nests in some populations. The similarity between presumed seed shadow (see Gibson 1993 for the vicarious Melampyrum lineare) and plant distribution suggests that achieved colonization of Melampyrum pratense is mainly controlled by the seed dispersal curves of the advancing populations (cf. Willson 1993; Brunet \& Oheimb 1998).

Matlack (1994) suggests that negative exponential distributions which have no isolated individuals at great distance would indicate colonization by the advance of a wave front, and species with a negative logarithmic colonization model expand their population by the establishment of isolated individuals and the subsequent gradual infill of the gaps between them. Contrary to my results, a logarithmic decrease 
was most common for ant-dispersed woodland herbs colonizing recent deciduous forests contiguous to ancient forests in eastern North America (Matlack 1994), southern Sweden (Brunet \& Oheimb 1998) and Belgium (Bossuyt et al. 1999; Honnay et al. 1999). A negative exponential decrease, indicating a wave front, occurred only with Convallaria majalis and Polygonatum multiflorum (Bossuyt et al. 1999), presumed barochorous species which spread mainly by clonal growth from existing patches. Despite the fact that the best fit were negative exponential regressions for the advancing Melampyrum pratense populations, my results do not contradict colonization patterns of myrmecochores of ancientrecent forest ecotones. Steeper decreases in population density resulting in exponential models were recorded, as the colonization occurred in all directions and not across a linear border as in the aforementioned studies. Hence, the area which is to be colonized within a certain distance increases drastically with distance from the sown plot. Consequently, plotting the individual number against the distance (Fig. 6) leads to similar results to those in the afore-mentioned studies.

\section{Conclusions for the colonization of myrmecochores}

Despite the relatively short experimental period and the observed differences between the studied populations, a generalization of my results regarding migration of Melampyrum pratense in temperate acidsoil mixed forests may be possible. As is the case for most deciduous forest herbs (e.g. Matlack 1994; Brunet \& Oheimb 1998), the data imply only a slow "step-by-step" colonization which may already be critical to overcome small barriers such as ways and forest-rides. However, the distances seeds moved during the experiment correlate poorly with the great distances from source populations over which occasional successful colonization of recent woodlands in northern Germany by Melampyrum pratense are achieved (cf. Heinken 1998). Great distances were also covered during Holocene migration from remote refugia up to northern Europe, which implies average migration rates of at least several hundred metres per year (cf. Brunet \& Oheimb 1998; Pakeman 2001). This suggests that occasional events leading to long-distance dispersal are the key to understanding both Holocene migration and the colonization of recent woodlands. Endozoochory may facilitate this "accidental dispersal" (Cain et al. 1998; Pakeman 2001), as Melampyrum pratense was recorded as germinating in dung of cattle (Stender et al. 1997). In the „Glauer Berge“ area herbivory, presumably by wild large mammals, was common. However, studies on endozoochorous dispersal by wild herbivores (roe deer, fallow deer, and hare) in NE German woodland areas by Heinken et al. (2001) indicate that endozoochory of Melampyrum pratense is very unlikely, as its large seeds will usually be destroyed during the chewing procedure and passage through the gut.

My results can be used as a colonization model of Melampyrum pratense after such an accidental long-distance dispersal. The high rates of germination and establishment may compensate the low probability of long-distance dispersal to some extent. However, as in the current study 300 seeds were sown and thus many more than transported by an accidental dispersal to a single site, the initial phase of population establishment will be prolonged in natural colonization. Nevertheless dispersal by ants proves to be a very effective mechanism for Melampyrum pratense to colonize unoccupied habitats in the direct vicinity of a population, as large amounts of seed are obviously transported to suitable microsites for seedling establishment.

However, a transfer of the conclusions in this study to other myrmecochorous woodland herbs is difficult, and more investigations should be conducted here. Migration rates of small-seeded species may be lower than those of the large-seeded Melampyrum pratense, because removal rates by ants increase, and seed-dropping rates decrease, with increasing seed size (Gorb \& Gorb 1995, 1999b). Moreover, besides their longer time period until the first seed is set, many perennial plant species with a more limited seed production and seedling recruitment (e.g. Ehrlén \& Eriksson 2000) may be far more restricted in their ability to disperse to new sites than the studied annual species (cf. Primack \& Miao 1992). Finally, ant populations will differ in different forest habitats. Thus, in an implantation experiment in a recent deciduous forest in Denmark, Petersen \& Philipp (2001) found mean migration rates of only 0.07-0.37 $\mathrm{m} \mathrm{yr}^{-1}$ for perennial myrmecochores (Corydalis cava, C. intermedia, Mercurialis perennis), as an absence of ants hindered the spread within the studied site. 


\section{Acknowledgements}

I wish to thank C. Schöning for collecting and identifying ant samples, and H. Lünser for preparing Fig. 2 and 4. Prof. Dr M. Diekmann, Prof. Dr W. Frey, F. Schaumann and Dr M. Wulf provided many helpful suggestions on how to improve the manuscript. Many thanks also to M. Lees, who polished my English.

\section{References}

Beattie, A.J. 1983. Distribution of ant-dispersed plants. Sonderband naturwissenschaftlicher Verein Hamburg 7: 249-270.

Bierzychudek, P. 1982. Life histories and demography of shade-tolerant temperate forest herbs: a review. New Phytologist 90: 757-776.

Bossuyt, B., Hermy, M. \& Deckers, J. 1999. Migration of herbaceous plant species across ancient-recent forest ecotones in central Belgium. Journal of Ecology 87: 628-638.

Brunet, J. \& Oheimb, G. von 1998. Migration of vascular plants to secondary woodlands in southern Sweden. Journal of Ecology 86: 429-438.

Brunet, J., von Oheimb, G. \& Diekmann, M. 2000. Factors influencing vegetation gradients across ancientrecent woodland borderlines in southern Sweden. Journal of Vegetation Science 11: 515-524.

Cain, M., Damman H. \& Muir, A. 1998. Seed dispersal and the Holocene migration of woodland herbs. Ecological Monographs 68: 325-347.

Culver, D.C. \& Beattie, A.J. 1978. Myrmecochory in Viola: dynamics of seed-ant interactions in some West Virginia species. Journal of Ecology 66: 53-72.

Dzwonko, Z. 2001. Migration of vascular plant species to a recent wood adjoining ancient woodland. Acta Societas Botanicorum Poloniae 70: 71-77.

Ehrlén, J. \& Eriksson, O. 2000. Dispersal limitation and patch occupancy in forest herbs. Ecology 81: 16671674.

Frantzen, J. \& van den Bosch, F. 2000. Spread of organisms: can travelling and dispersive waves be distinguished? Basic and Applied Ecology 1: 83-91.

Frey, W., Heinz, S., Hensen, I. \& Pfeiffer, T. 1999. Nahausbreitung bei Pflanzen - Ermittlung der Ausbreitungsweiten von Diasporen mittels Klebeplatten. Botanische Jahrbücher für Systematik 121: 75-84.

Gibson, W. 1993. Selective advantages to hemiparasitic annuals, genus Melampyrum, of a seed-dispersal mutualism involving ants I: Favourable nest sites. Oikos 67: 334-344.

Gorb, S.N. \& Gorb, E.V. 1995. Removal rates of seeds of five myrmecochorous plants by the ant Formica polyctena (Hymenoptera: Formicidae). Oikos 73: 367-374.

Gorb, S.N. \& Gorb, E.V. 1999a. Effects of ant species composition on seed removal in deciduous forest in eastern Europe. Oikos 84: 110-118.

Gorb, S.N. \& Gorb, E.V. 1999b. Dropping rates of elaiosome-bearing seeds during transport by ants (Formica polyctena Foerst.): Implications for distance dispersal. Acta Oecologia 20: 509-518.

Handel, S.N., Fisch, S.B. \& Schatz, G.E. 1981. Ants disperse a majority of herbs in a mesic forest community in New York State. Bulletin of the Torrey Botanical Club 108: 430-437.

Harper, J.L. 1977. Population biology of plants. Academic Press, New York.

Hegi, G. 1974. Illustrierte Flora von Mittel-Europa. Vol. VI/1. $2^{\text {nd }}$ ed.. Carl Hanser, München.

Heinken, T. 1998. Zum Einfluss des Alters von Waldstandorten auf die Vegetation in bodensauren Laubwäldern des niedersächsischen Tieflands. Archiv für Naturschutz und Landschaftsforschung 37: 201-232.

Heinken, T., Hanspach, H. \& Schaumann, F. 2001. Welche Rolle spielt die endozoochore Ausbreitung von Pflanzen durch wildlebende Säugetiere? Untersuchungen in zwei brandenburgischen Waldgebieten. Hercynia N.F. 34: 237-259.

Heithaus, E.R. 1986. Seed dispersal mutualism and the population density of Asarum canadense, an antdispersed plant. pp. 199-210. In: Estrada, A., Fleming, T.H. (eds.), Frugivores and seed dispersal. Dr. W. Junk Publishers, Dordrecht.

Hermy, M., Honnay, O., Firbank, L., Grashof-Bokdam, C. \& Lawesson, J.E. 1999. An ecological comparison between ancient and other forest plant species of Europe, and the implications for forest conservation. Biological Conservation 91: 9-22.

Higashi, S., Tsuyuzaki, S., Ohara, M. \& Ito, F. 1989. Adaptive advantages of ant-dispersed seeds in the myrmecochorous plant Trillium tschoskii (Liliaceae). Oikos 54: 389-394.

Higgins, S.L. \& Richardson, D.M. 1999. Predicting plant migration rates in a changing world: The role of long-distance dispersal. The American Naturalist 153: 464-475.

Honnay, O., Hermy, M. \& Coppin, P. 1999. Impact of habitat quality on forest plant species colonization. Forest Ecology and Management 115: 157-170.

Kalisz, S., Hanzawa, F.M., Tonsor, S.J., Thiede, D.A. \& Voigt, S. 1999. Ant-mediated seed dispersal alters pattern of relatedness in a population of Trillium grandiflorum. Ecology 80: 2620-2634. 
Kjellsson, G. 1985. Seed fate in a population of Carex pilulifera L. I. Seed dispersal and ant-seed mutualism. Oecologia 85: 416-423.

Kot, M., Lewis, M.A. \& van den Driesche, P. 1996. Dispersal data and the spread of invading organisms. Ecology 77: 2027-2042.

Lozan, J. 1992. Angewandte Statistik für Naturwissenschaftler. Paul Parey, Berlin \& Hamburg.

Masselink, A.K. 1980. Germination and seed population dynamics in Melampyrum pratense L. Acta Botanica Neerlandica 29: 451-468.

Matthies, D. 1991. Die Populationsbiologie der annuellen Hemiparasiten Melampyrum arvense, Melampyrum cristatum, Melampyrum nemorosum (Scrophulariaceae). Dissertation, Ruhr-Universität Bochum.

Matlack, G.R. 1994. Plant species migration in a mixed-history forest landscape in eastern North America. Ecology 75: 1491-1502.

Ohara, M. \& Higashi, S. 1987. Interference by grounds beetles with the dispersal by ants of seeds of Trillium species (Liliaceae). Journal of Ecology 75: 1091-1098.

Ohkawara, K. \& Higashi, S. 1994. Relative importance of ballistic and ant dispersal in two diplochorous Viola species (Violaceae). Oecologia 100: 135-140.

Ohkawara, K., Higashi, S. \& Ohara, M. 1996. Effects of ants, ground beetles and the seed-fall patterns on myrmecochory of Erythronium japonicum Deene (Liliaceae). Oecologia 106: 500-506.

Oostermeijer, J.G.B. 1989. Myrmecochory in Polygala vulgaris L., Luzula campestris (L.) D.C. and Viola curtisii Forster in a Dutch Dune area. Oecologia 78: 302-311.

Pakeman, R.J. 2001. Plant migration rates and seed dispersal mechanisms. Journal of Biogeography 28: 795800.

Petersen, P.M. \& Philipp, M. 2001. Implantation of forest plants in a wood on former arable land: a ten year experiment. Flora 196: 286-291.

Poschlod, P., Bakker, J., Bonn, S. \& Fischer, S. 1996. Dispersal of plants in fragmented landscapes. pp. 123127. In: Settele, J., Margules, C.R., Poschlod, P., Henle, K. (eds.), Species survival in fragmented landscapes. Kluwer Academic Publishers, Dordrecht.

Primack, R.B. \& Miao, S.L. 1992. Dispersal can limit local plant distribution. Conservation Biology 6: 513519.

Pudlo, R.J., Beattie, A.J. \& Culver, D.C. 1990. Population consequences of changes in an ant seed mutualism in Sanguinaria canadensis. Oecologia 46: 32-37.

Salisbury, E.J. 1942. The reproductive capacity of plants. Bell, London.

Sernander, R. 1906. Entwurf einer Monographie der europäischen Myrmekochoren. Kunglika Svenska Vetenskapsakademie Handlingar 41: 1-410.

Shigesada, N. \& Kawasaki, K. 1997. Biological invasions: theory and practice. Oxford University Press, Oxford.

Silvertown, J. \& Charlesworth, D. 2001. Introduction to plant population biology. $4^{\text {th }}$ ed.. Blackwell Science, Oxford etc..

Smith, B.H., Forman, P.D. \& Boyd, A.E. 1989. Spatial patterns of seed dispersal and predation of two myrmecochorous forest herbs. Ecology 70: 1649-1656.

Stender, S., Poschlod, P., Vauk-Hentzelt, E. \& Dernedde, T. 1997. Die Ausbreitung von Pflanzen durch Galloway-Rinder. Verhandlungen der Gesellschaft für Ökologie 27: 173-180.

Ter Borg, S.J. 1985. Population biology and habitat relations of some hemiparasitic Scrophulariaceae. pp. 463487. In: White, J. (ed.), The population structure of vegetation. Dr. W. Junk Publishers, The Hague.

Thompson, K., Bakker, J.P. \& Bekker, R.M. 1997. The soil seed banks of North West Europe: Methodology, density and longevity. Cambridge University Press, Cambridge.

Verheyen, K., Bossuyt, B., Hermy, M. \& Tack, G. 1999. The land use history (1278-1990) of a mixed hardwood forest in western Belgium and its relationship with chemical soil characteristics. Journal of Biogeography 26: 1115-1128.

Verheyen, K. \& Hermy, M. 2001a. The relative importance of dispersal limitation of vascular plants in secondary forest succession in Muizen Forest, Belgium. Journal of Ecology 89: 829-840.

Verheyen, K. \& Hermy, M. 2001b. An integrated analysis of the spatio-temporal colonization patterns of forest plant species. Journal of Vegetation Science 12: 567-578.

Willson, M.F. 1993. Dispersal mode, seed shadows, and colonization patterns. Vegetatio 107/108: 261-280.

Winkler, E. \& Matthies, D. 2001. Extinction risk for populations of Melampyrum arvense: a simulation study. Verhandlungen der Gesellschaft für Ökologie 31: 26.

Wulf, M. 1997. Plant species as indicators of ancient woodland in northwestern Germany. Journal of Vegetation Science 8: 635-644. 